\title{
Optimum mix for the geopolymer concrete
}

\author{
M.I. Abdul Aleem ${ }^{1 *}$ and P.D. Arumairaj ${ }^{2}$ \\ ${ }^{1 *}$ Department of Civil Engineering, Sri Ramakrishna Institute of Technology, Coimbatore -641010, India \\ ${ }^{2}$ Department of Civil Engineering, Government. College of Technology, Coimbatore -641013, India \\ aleemces@gmail.com*, arumairajcbe@gmail.com
}

\begin{abstract}
Geopolymer concrete utilizes an alternate material including fly ash as binding material in place of cement. This fly ash reacts with alkaline solution (e.g., $\mathrm{NaOH})$ and Sodium Silicate $\left(\mathrm{Na}_{2} \mathrm{SiO}_{3}\right)$ to form a gel which binds the fine and coarse aggregates. Since Geopolymer concrete is the emerging field, the guidelines from the Bureau of Indian Standards are yet to be formulated. An attempt has been made to find out an optimum mix for the Geopolymer concrete. Concrete cubes of size $150 \times 150 \times 150 \mathrm{~mm}$ were prepared and cured under steam curing for 24 hours. The compressive strength was found out at 7 days and 28 days. The results are compared. The optimum mix is Fly ash: Fine aggregate: Coarse aggregate (1:1.5:3.3) with a solution $\left(\mathrm{NaOH} \& \mathrm{Na}_{2} \mathrm{SiO}_{3}\right.$ combined together) to fly ash ratio of 0.35 . High and early strength was obtained in the Geopolymer concrete mix.
\end{abstract}

Keywords: Geopolymer concrete, optimum mix ratio

Introduction

Geopolymer cement (Davidovits, 1984, 2008, 2010) represents a broad range of materials characterized by networks of inorganic molecule. The fly ash which has high content of Silica (Si) and Alumina (Al) reacts with alkaline solution like Sodium Hydroxide $(\mathrm{NaOH})$ or Potassium Hydroxide (KOH) and Sodium Silicate $\left(\mathrm{Na}_{2} \mathrm{SiO}_{3}\right)$ or Potassium Silicate $\left(\mathrm{K}_{2} \mathrm{SiO}_{3}\right)$ and forms a gel which binds the fine and coarse aggregates. Geopolymer concrete do not require any water for matrix bonding, instead the alkaline solution react with Silicon and Aluminium present in the flyash. The polymerisation process involves a substantially fast chemical reaction under alkaline condition on Si-Al minerals.

Fig 1. SEM image of fly ash

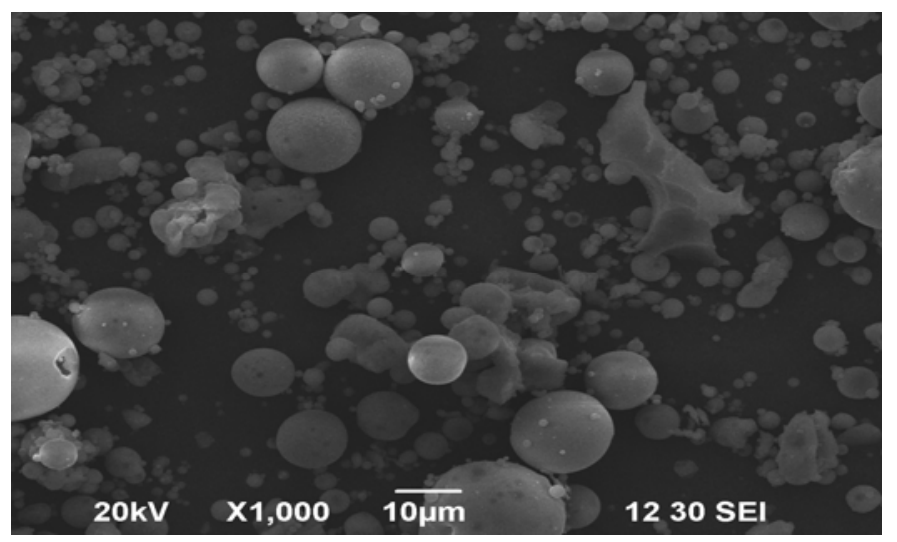

Constituents of fly ash and the chemical reaction

The fly ash was obtained from Thermal Power Station, Mettur, Tamil Nadu, India. This fly ash is of class F. The SEM (Scanning Electron Microscope) analysis was carried out and the image is presented in Fig.1. An EDAX (Energy Dispersive and X-ray Technique) test was carried out on the fly ash and the constituents are

Fig. 2. The schematic formation of Geopolymer Concrete

$\mathrm{n}\left(\mathrm{Si}_{2} \mathrm{O}_{5}, \mathrm{Al}_{2} \mathrm{O}_{2}\right)+2 \mathrm{nSiO}_{2}+4 \mathrm{nH}_{2} \mathrm{O}+\mathrm{NaOH}$ or $\mathrm{KOH} \rightarrow \mathrm{Na}^{+}, \mathrm{K}^{+}+\mathrm{n}(\mathrm{OH})_{3}-\mathrm{Si}-\mathrm{O}-\mathrm{Al}-\mathrm{O}-\mathrm{Si}-(\mathrm{OH})_{3}$ ( $\mathrm{Si}$-Al materials)
$(\mathrm{OH})_{2}$ (Geopolymer precursor)

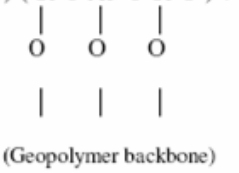

M.I.A.Aleem \& P.D.Arumailraj Indian J.Sci.Technol. 
Table 1. Constituents of fly ash

\begin{tabular}{|l|l|l|l|l|l|}
\hline Element & $\begin{array}{l}\text { App. } \\
\text { Const. }\end{array}$ & Intensity & $\begin{array}{l}\text { Weight } \\
\%\end{array}$ & $\begin{array}{c}\text { Weight } \\
\% \text { Sigma }\end{array}$ & $\begin{array}{c}\text { Atomic } \\
\%\end{array}$ \\
\hline $\mathrm{C}$ & 4.29 & 0.2747 & 8.34 & 2.52 & 13.15 \\
\hline $\mathrm{O}$ & 82.17 & 0.8606 & 50.95 & 1.50 & 60.32 \\
\hline $\mathrm{Mg}$ & 0.55 & 0.7768 & 0.37 & 0.09 & 0.29 \\
\hline $\mathrm{Al}$ & 22.96 & 0.8770 & 13.98 & 0.46 & 9.81 \\
\hline $\mathrm{Si}$ & 31.76 & 0.7869 & 21.54 & 0.67 & 14.53 \\
\hline $\mathrm{K}$ & 1.50 & 0.9855 & 0.81 & 0.09 & 0.39 \\
\hline $\mathrm{Ca}$ & 0.91 & 0.9496 & 0.51 & 0.08 & 0.24 \\
\hline $\mathrm{Ti}$ & 1.90 & 0.8092 & 1.26 & 0.13 & 0.50 \\
\hline $\mathrm{Fe}$ & 3.44 & 0.8193 & 2.24 & 0.19 & 0.76 \\
\hline
\end{tabular}

\section{Materials used}

The fine aggregates (karur sand) were obtained from the local supplier at Coimbatore, Tamil Nadu, India. The coarse aggregates were collected from a local approved Crusher Unit, Coimbatore, Tamil Nadu, India.

Sodiumium Hydroxide ( $\mathrm{NaOH}$ ) is available in the local market in pellet form. 10 Molar solution was used. Since the molecular weight of Sodium Hydroxide is 40 , and in order to prepare 10 molar solution $10 \times 40=400 \mathrm{gms}$ of Sodium Hydroxide was dissolved in $1000 \mathrm{ml}$ of water.

Sodium Silicate $\left(\mathrm{Na}_{2} \mathrm{SiO}_{3}\right)$ is also commercially available in the market. The sodium silicate solution (A53) with a ratio of $\mathrm{SiO}_{2}$ to $\mathrm{Na}_{2} \mathrm{O}$ is approximately 2 was used. That is $29.4 \% \mathrm{SiO}_{2}, 14.7 \% \mathrm{Na}_{2} \mathrm{O}$ and $55.9 \%$ of water.

\section{Mix proportions}

The previous studies on Geopolymer concrete ((Van Chanh Bui et al., 2008; Wallah \& Rangan, 2006)) used a mix proportion of fly ash: Fine Aggregate: Coarse Aggregate are 1:1.35:3.17 with a solution $(\mathrm{NaOH} \&$ $\mathrm{Na}_{2} \mathrm{SiO}_{3}$ combined together) to fly ash ratio of 0.35 . Four trail mixes were arrived by slightly modifying the quantities of fine and coarse aggregates. The proposed mix ratios are: Trial Mix I - : 1:1.3:3.10; Trial Mix II - : $1: 1.4$ : 3.20; Trial Mix III- : $1: 1.5: 3.30$; Trial Mix IV- : $1: 1.6$ : 3.40 . For all the four trial mixes, the solution to fly ash ration was kept same as 0.35 . The exact quantities for 1 cubic metre are presented in Table 2, 3, 4 and 5.

Preparation of alkaline solution: Prof. Davidovits, (Geopolymer Institute, France) has recommended that

\section{Fig. 3. Preparation of Geopolymer concrete}

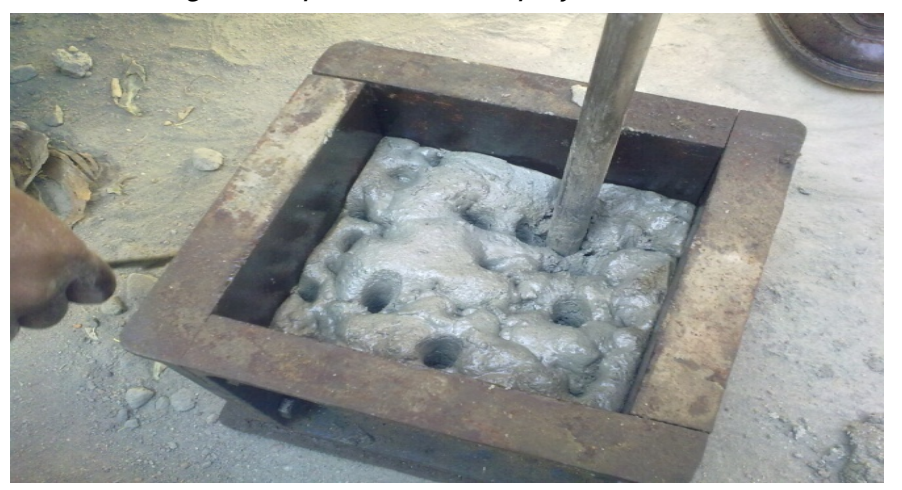

the sodium silicate solution and the sodium hydroxide solution were mixed together one day prior to the use in preparing the geopolymer concrete. This is followed in this study. The ratio of sodium silicate solution to sodium hydroxide solution was fixed as $2.5 \%$.

Mixing of Geopolymer concrete: The fly ash, fine aggregates and coarse aggregates were mixed manually in a container and then the alkaline solution was added to prepare the geopolymer concrete. The geopolymer concrete was placed in $150 \mathrm{~mm}$ cube moulds in three layers and each layer was compacted by giving 25 blows with a $25 \mathrm{~mm}$ tamping rod. The Geopolymer concrete was dark in colour with shiny appearance as shown in Fig.3 and a workable mix.

Table 2. Trial mix - I (1:1.3:3.10)

\begin{tabular}{|l|l|}
\hline \multicolumn{1}{|c|}{ Materials } & $\mathrm{Kg} / \mathrm{m}^{3}$ \\
\hline Fly ash (Class F) & 408.00 \\
\hline Fine sand & 530.40 \\
\hline Coarse aggregate (20mm in size) & 1264.80 \\
\hline Sodium silicate solution & 103.00 \\
\hline $\begin{array}{l}\text { Sodium hydroxide solution(10 } \\
\text { Molar) }\end{array}$ & 41 \\
\hline
\end{tabular}

Table 3. Trial Mix - // $(1: 1.4: 3.20)$

\begin{tabular}{|l|c|}
\hline \multicolumn{1}{|c|}{ Materials } & $\mathrm{Kg} / \mathrm{m}^{3}$ \\
\hline Fly ash (Class F) & 408.00 \\
\hline Fine sand & 571.20 \\
\hline Coarse aggregate (20mm in size) & 1305.60 \\
\hline Sodium silicate solution & 103.00 \\
\hline Sodium hydroxide solution(10 Molar) & 41.00 \\
\hline
\end{tabular}

Table 4. Trial Mix - III (1: $1.5: 3.3)$

\begin{tabular}{|l|c|}
\hline \multicolumn{1}{|c|}{ Materials } & $\mathrm{Kg} / \mathrm{m}^{3}$ \\
\hline Fly ash (Class F) & 408.00 \\
\hline Fine sand & 612.00 \\
\hline Coarse aggregate (20mm in size) & 1346.40 \\
\hline Sodium silicate solution & 103.00 \\
\hline Sodium hydroxide solution(10 Molar) & 41.00 \\
\hline
\end{tabular}

\begin{tabular}{|l|l|}
\multicolumn{2}{|c|}{ Table 5. Trial Mix $-I V(1: 1.6: 3.4)$} \\
\hline \multicolumn{1}{|c|}{ Materials } & $\mathrm{Kg} / \mathrm{m}^{3}$ \\
\hline Fly ash (Class F) & 408.00 \\
\hline Fine sand & 652.80 \\
\hline Coarse aggregate $(20 \mathrm{~mm}$ in size) & 1387.20 \\
\hline Sodium silicate solution & 103.00 \\
\hline Sodium hydroxide solution(10 Molar) & 41.00 \\
\hline
\end{tabular}

\section{Curing}

The previous studies on Geopolymer concrete revealed that geopolymer concrete did not attain any strength at room temperature or by water curing. The Geopolymer concrete will harden at steam curing or hot air curing and the minimum curing period shall be 24 hours. After casting the specimens, they were kept in rest period in room temperature for 2 days. The term 'Rest Period' was coined to indicate the time taken from the completion of casting of test specimen to the start of 
curing at an elevated temperature. The geopolymer concrete was demoulded and then placed in an autoclave for steam curing for 24 hours at a temperature of $60^{\circ} \mathrm{C}$. The cubes were then allowed to cool in room temperature for 24 hours.

Table 6. Compressive strength $(\mathrm{N} / \mathrm{mm} 2)$ in 7 days

\begin{tabular}{|c|c|c|c|}
\hline Trial Mix I & Trial Mix II & Trial Mix III & Trial Mix IV \\
\hline$(1: 1.3: 3.10)$ & $(1: 1.4: 3.20)$ & $1: 1.5: 3.3$ & $(1: 1.6: 3.4)$ \\
\hline 32.0 & 43.5 & 47.0 & 42.0 \\
\hline 36.5 & 42.5 & 48.5 & 41.5 \\
\hline 38.0 & 41.0 & 48.0 & 39.8 \\
\hline \multicolumn{4}{|c|}{ Values in parentheses represent the ratio of mix } \\
\hline
\end{tabular}

\section{Compressive Strength Test}

The cube specimens were tested in a compressive testing machine having $2000 \mathrm{kN}$ capacity in accordance with the Bureau of Indian Standard test procedures. The compression test results are tabulated in Table $6 \& 7$. The results of 28 days compressive strength is presented in Fig. 4.

Table 7. Compressive strength $(\mathrm{N} / \mathrm{mm} 2)$ in 28 days

\begin{tabular}{|l|l|l|l|}
\hline Trial Mix I & Trial Mix II & Trial Mix III & Trial Mix IV \\
\hline$(1: 1.3: 3.10)$ & $(1: 1.4: 3.20)$ & $(1: 1.5: 3.3)$ & $(1: 1.6: 3.4)$ \\
\hline 37.33 & 47.11 & 51.55 & 48.88 \\
\hline 39.11 & 48.0 & 53.33 & 49.33 \\
\hline 42.66 & 47.55 & 52.44 & 48.00 \\
\hline \multicolumn{4}{|l|}{ Values in parentheses represent the ratio of mix } \\
\hline
\end{tabular}

Fig. 4. Compressive strength of various mixes

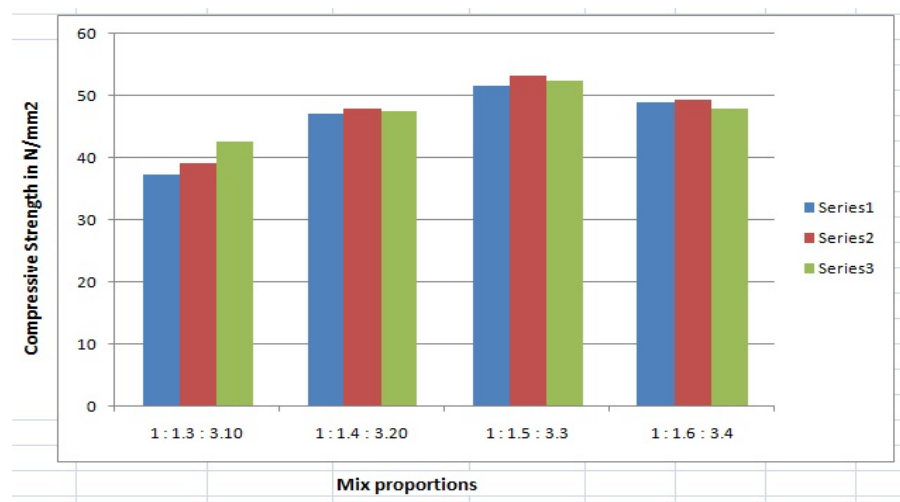

Results and discussion

The Geopolymer concrete showed high performance with respect to the strength. The Geopolymer concrete was a good workable mix. High early strength was obtained in the Geopolymer concrete mix. The increase in percentage of fine aggregates and coarse aggregates increased the compressive strength up to the optimum level. This may be due to the high bonding between the aggregates and alkaline solution. The compressive strength was found reduced beyond the optimum mix. This may be due to the increase in volume of voids between the aggregates. The optimum mix is- Fly ash: Fine aggregate: Coarse aggregate are 1:1.5:3.3 with a solution ( $\mathrm{NaOH} \& \mathrm{Na}_{2} \mathrm{SiO}_{3}$ combined together) to fly ash ratio of 0.35 .

\section{References}

1. Davidovits J (1984) Pyramids of Egypt made of man-made Stone, Myth or fact. Symp. on Archaeometry. Smithsonian Institution, Washington, DC.

2. Davidovits J (2008) Geopolymer chemistry and applications. Institut Géopolymère, Saint-Quentin, France.

3. Davidovits J (2010) What Is a Geopolymer? Introduction. Institut Géopolymère, Saint-Quentin, France. Accessed on January 29 at http://www.geopolymer.org/science/introduction.

4. Hardjito D, Wallah S, Sumajouw DMJ and Rangan BV (2004) On the development of fly ash-based geopolymer Concrete. ACl. Mater. J, 101 (6), 467472.

5. Van Chanh Bui, Dang Trung and Dang Van Tuan (2008) Recent research geopolymer concreteNguyen during the $3^{\text {rd }}$ ACF Int.Conf.-ACF/VCA.

6. Wallah SE and Rangan BV (2006) Low calcium fly ash based geopolymer concrete-Long term properties. Res. Report-GC2, Curtin University, Australia. pp:76-80.
M.I.A.Aleem \& P.D.Arumailraj Indian J.Sci.Technol. 